\title{
PENERAPAN METODE FUZZY ANALYTICAL HIERARCHY PROCESS (F-AHP) DALAM MEMILIH APARTEMEN BERDASARKAN PREFERENSI MASYARAKAT DI KOTA SURAKARTA
}

\author{
Atanasia Gretta Rida Kusuma Anggita ${ }^{1)}$, Setiono ${ }^{2)}$, Sugiyarto ${ }^{3)}$ \\ 1) Mahasiswa Jurusan Teknik Sipil, Fakultas Teknik, Universitas Sebelas Maret \\ 2),3) Pengajar Jurusan Teknik Sipil, Fakultas Teknik, Universitas Sebelas Maret \\ Jl. Ir. Sutami 36 A Surakarta \\ Email: grettarida782@gmail.com
}

\begin{abstract}
Surakarta City is one of the cities in Central Java with the fastest development. With such rapid development, Surakarta City is one of the cities with a center for economic, trade, education, cultural and other informal sector activities. This situation on the one hand creates housing problems for the society but on the other hand is an opportunity for developers or developers to provide residential facilities by building the apartments needed. In addition, due to developments in these various sectors including the investment sector, many people choose to invest in property in Surakarta by buying apartments and then renting it or expecting a significant increase in prices when they sell it. Therefore, the purpose of this study is to determine people's preferences in choosing an apartments and find out the most factor affects people's preferences in choosing an apartments in Surakarta City. For this reason, it is necessary to conduct research related to people's preferences in choosing an apartments. This study uses Fuziy Analytical Hierarchi Process (F-AHP) method with belp of Microsoft Excel 2013 software. Data obtained by spreading questionnaires to owners and tenants of 3 predetermined review apartments. The results showed that the factor that most influenced society in choosing an apartments was legality.
\end{abstract}

Keyword : Choosing apartments, Fuzzy Analytical Hierarchy Process (F-AHP), populations preferences

\begin{abstract}
Abstrak
Kota Surakarta merupakan salah satu kota di Jawa Tengah yang perkembangannya paling pesat. Dengan perkembangan yang demikian pesat, maka Kota Surakarta merupakan salah satu kota dengan pusat kegiatan perekonomian, perdagangan, pendidikan, kebudayaan, dan sektor informal lainnya. Keadaan ini di satu sisi menimbulkan masalah tempat tinggal bagi masyarakat tetapi di sisi lain merupakan peluang bagi kalangan developer atau pengembang untuk menyediakan sarana hunian dengan membangun apartemen yang dibutuhkan. Di sisi lain, karena perkembangan di berbagai sektor tersebut termasuk sektor investasi, banyak masyarakat yang memilih untuk berinvestasi dibidang properti di Surakarta yaitu dengan membeli apartemen lalu disewakan atau mengharapkan kenaikan harga yang signifikan saat mereka nanti menjualnya. Oleh karena itu, tujuan penelitian ini adalah untuk mengetahui preferensi masyarakat dalam memilih apartemen dan mengetahui faktor yang paling mempengaruhi preferensi masyarakat dalam memilih apartemen di Kota Surakarta. Untuk itu, perlu dilakukan penelitian terkait preferensi masyarakat dalam memilih apartemen. Dalam penelitian ini digunakan metode Furzy Analytical Hierarchy Process (F-AHP) dengan bantuan software Microsoft Excel 2013. Data didapatkan dengan cara menyebar kuisioner kepada pemilik maupun penyewa dari 3 apartemen tinjauan yang telah ditentukan. Dari hasil penelitian didapatkan bahwa faktor yang paling mempengaruhi masyarakat dalam memilih apartemen yaitu faktor legalitas.
\end{abstract}

Kata Kunci : Furzy Analytical Hierarchy Process (F-AHP), pemilihan apartemen, preferensi masyarakat

\section{PENDAHULUAN}

Pertumbuhan penduduk akan menuntut sebuah kota untuk memenuhi kebutuhan papan penghuninya. Hal ini juga terjadi di Kota Surakarta. Dengan lahan yang semakin terbatas untuk dijadikan tempat tinggal, Pemkot Surakarta berencana menjadikan Kota Solo sebagai kota bisnis dengan membangun mall dan apartemen serta kawasan komesial. Dengan adanya apartemen makan diharapkan hal tersebut mampu mengatasi kebutuhan masyarakat akan kebutuhan tinggal ditengah luas lahan yang semakin berkurang.

Selain itu, Kota Surakarta saat ini telah menjadi kota paling seksi nomor satu di Indonesia untuk investasi. Banyak sektor yang meningkat serta banyak pula ritel dan consumer good yang masuk di Kota Solo. Hal ini menandakan bahwa perekonomian di Kota Solo sangat bagus. Pertumbuhan yang paling pesat yaitu di bidang properti, tidak hanya banyaknya bangunan perumahan dan hotel yang sedang dikerjakan melainkan pembangunan apartemen pun meningkat di Kota Surakarta.

Pembangunan apartemen perlu ditingkatkan dan dikembangkan secara terpadu dan terarah. Hal ini perlu mempertimbangkan berbagai aspek sehingga bisa meningkatkan kualitas kehidupan manusia dalam bermasyarakat dan berkeluarga. Masyarakat perlu bersikap pandai dalam meilih apartemen mana yang sesuai dengan kriteria 
mereka. Maka, digunakanlah metode pengambilan keputusan yaitu Fuz:y Analytical Hierarchy Process (F-AHP) untuk mengetahui preferensi masyarakat dalam memilih apartemen di Kota Surakarta.

\section{METODE}

Metode yang digunakan dalam penelitian ini yaitu deskriptif kualitatif dengan mengidentifikasi faktor-faktor yang paling berpengaruh dalam memilih apartemen. Data yang digunakan yaitu data primer yang berupa data hasil kuisioner. Dan data sekunder yang digunakan yaitu berasal dari berbagai sumber yaitu buku referensi, jurnal, internet, penelitian terdahulu serta brosur-brosur dari apartemen tinjauan.

Metode pengolahan data yang digunakan yaitu metode deskriptif dan metode pembobotan menggunakan metode Fuzzy Analytical Hierarchy Process (F-AHP) dengan bantuan software Microsoft Excel 2013.

Pengolahan data dilakukan untuk mencari nilai pembobotan dalam menentukan kriteria yang paling dipilih oleh konsumen dalam memilih apartemen. Adapun tahapan pengolahan data yang dilakukan sebagai berikut:

1. Rekapitulasi hasil penilain kuesioner.

2. Menghitung entri matriks dan prioritas relatif setiap kriteria.

3. Menentukan nilai vektor prioritas/eigen vector.

4. Menentukan nilai $\lambda$ maks.

5. Mengukur konsistensi data.

6. Mengkonversi skala linguistik AHP menjadi Triangular Fuz:y Number.

7. Menentukan nilai Fuz:y Synthetic Extent (FSE).

8. Menghitung Degree of Possibility.

9. Melakukan normalisasi bobot.

Apartemen adalah kamar atau beberapa kamar (ruangan) yang diperuntukkan sebagai tempat tinggal, terdapat di dalam suatu bangunan yang biasanya mempunyai kamar atau ruangan-ruangan lain semacam itu. (Poerwadarminta, 1991).

\section{Tujuan Pembangunan Apartemen}

Berikut adalah tujuan pembangunan apartemen menurut Arie S. Hutagalung

1. Untuk memenuhi kebutuhan tempat tinggal yang layak.

2. Menjadikan tempat tinggal yang selaras, dan seimbang.

3. Mengurangi daerah yang kumuh.

4. Mengefektifkan lahan yang ada di perkotaan.

5. Mendorong permukiman yang padat penduduk.

\section{Teori Penentuan Lokasi Apartemen}

Teori ini didapatkan dari jurnal dan penelitian yang terdahulu. Berikut teori penentuan lokasi apartemen yang penulis gunakan:

1. Lust

Lust mengatakan bahwa kenyamanan dan keamanan dari suatu rumah ditentukan oleh lokasinya.

2. Utility Maximization

Pemilihan lokasi tempat tinggal dipengaruhi oleh biaya perpindahan dan menyebabkan individu akan memilih tempat tinggal yang dekat dengan tempat kerjanya.

3. Bourne

Beberapa pertimbangan yang mempengaruhi pemilihan lokasi apartemen yaitu : aksesibilitas ke pusat kota, lingkungan fisik dan sosial, harga lahan, dan fasilitas layanan kota.

4. Goodall

Pertimbangan sebuah keluarga dalam memilih rumah yaitu suasana di lingkungan, lokasi perumahan, keadaan rumah, kelengkapan fasilitas, nilai prestis, harga rumah, dan pendapat keluarga.

5. Yance onggo dkk

Ada beberapa faktor yang mempengaruhi keputusan untuk membeli apartemen yaitu faktor produk, faktor harga, faktor lokasi, faktor fasilitas, dan faktor promosi.

6. Rabinowitz dalam Catanese

Terdapat beberapa hal yang harus diperhatikan dalam memilih lokasi hunian yaitu hukum dan lingkungan, utilitas, faktor teknis, aksesibilitas, estetika, masyarakat, pelayanan kota, dan biaya. 


\section{Analytical Hierarchy Process (AHP)}

Pada tahun 1970 dikembangkan metode AHP oleh Thomas L. Saaty. Metode AHP memproses masalah multikriteria yang kompleks menjadi suatu model hirarki. Struktur hirarki terdiri dari level pertama adalah tujuan, lalu level kriteria, sub kriteria, dan seterusnya ke bawah hingga level terakhir yaitu level alternatif. Sebuah masalah yang rumit dapat diuraikan secara lebih sederhana dan sistematis bila disusun struktur hierarkinya.

Adapun tahap-tahap metode AHP menurut Apriyanto (2008) yaitu :

1. Merinci masalah dan menetapkan tujuan.

2. Membuat struktur hirarki.

3. Membentuk matriks perbandingan berpasangan.

4. Menguji konsistensi.

\section{Fuzzy Analitycal Hierarchy Process (F-AHP)}

F-AHP merupakan metode perangkingan yang merupakan gabungan dari metode AHP dan konsep fuzzy. Untuk menutupi kelemahan AHP yaitu kriteria memiliki sifat subjektif lebih banyak, maka dibuatlah sebuah metode dengan pendekatan fuzzy yaitu metode F-AHP. Triangular Fuzzy Number digunakan untuk menentukan derajat keanggotaan pada F-AHP. TFN bisa dilihat pada Gambar 1.

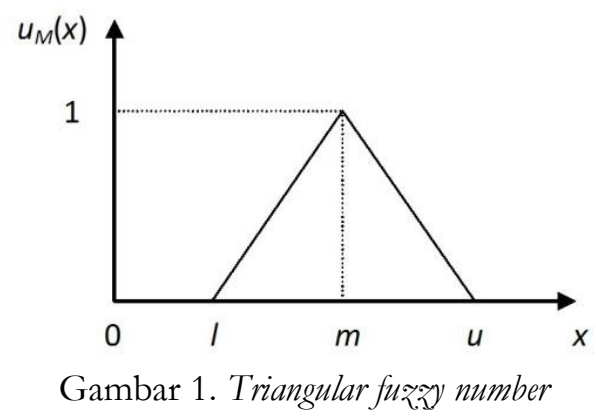

\section{HASIL DAN PEMBAHASAN}

Analisis bobot dilakukan menggunakan metode Fuz:y Analytical Hierarchy Process (F-AHP) dengan bantuan software Microsoft Excel 2013. Terdapat lima faktor utama yang menjadi kriteria penilaian, setelah dilakukan analisis, didapatkan bobot nilai terbesar untuk faktor utama pada faktor legalitas sebesar 24,86\%. Kemudian faktor dengan nilai bobot terkecil adalah faktor fasilitas apartemen sebesar 15,49\%. Lihat Gambar 2.

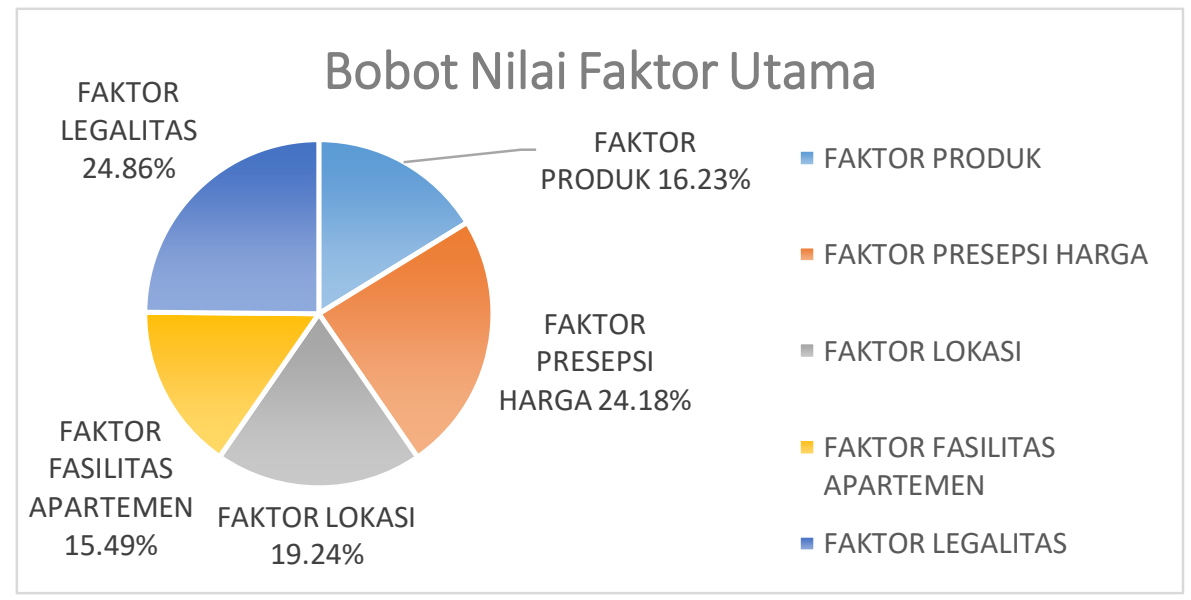

Gambar 2. Bobot nilai faktor utama 
Terdapat empat subfaktor pada faktor produk yang menjadi kriteria penilaian, setelah dilakukan analisis, didapatkan bobot nilai terbesar pada subfaktor potensi untuk disewakan (yield) dan kenaikan harga (capital gain) sebesar 49,03\%. Kemudian subfaktor dengan nilai bobot terkecil adalah subfaktor reputasi kontraktor yang membangun sebesar $11,22 \%$. Lihat Gambar 3.

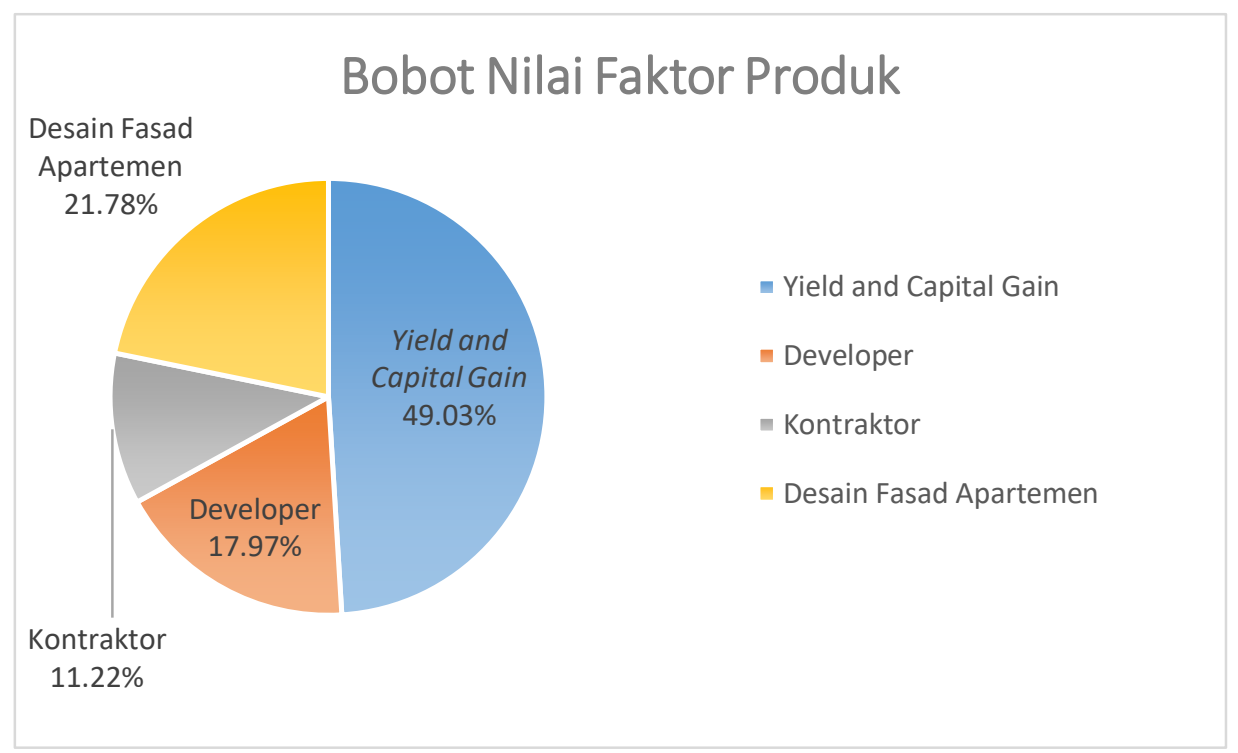

Gambar 3. Bobot nilai faktor produk

Terdapat tiga subfaktor pada faktor persepsi harga yang menjadi kriteria penilaian, setelah dilakukan analisis, didapatkan bobot nilai terbesar pada subfaktor harga sebesar 40,43\%. Kemudian subfaktor dengan nilai bobot terkecil adalah subfaktor besar DP (Down Payment)/uang muka minimum KPA sebesar 29,11\%. Lihat Gambar 4.

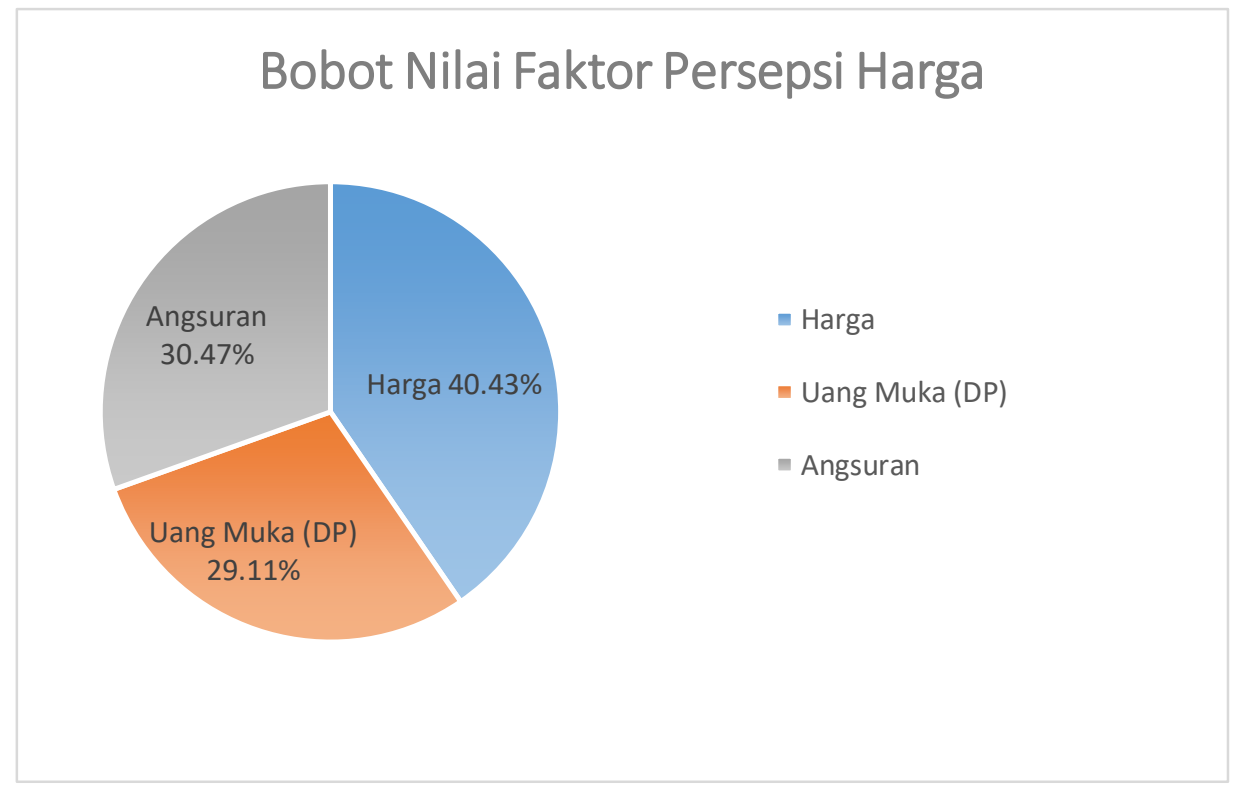

Gambar 4. Bobot nilai faktor harga

Terdapat tiga subfaktor pada faktor lokasi yang menjadi kriteria penilaian, setelah dilakukan analisis, didapatkan bobot nilai terbesar pada subfaktor dekat dengan fasilitas sosial sebesar 39,69\%. Kemudian subfaktor dengan nilai bobot terkecil adalah subfaktor terjangkau oleh transportasi umum sebesar 21,82\%. Lihat Gambar 5. 


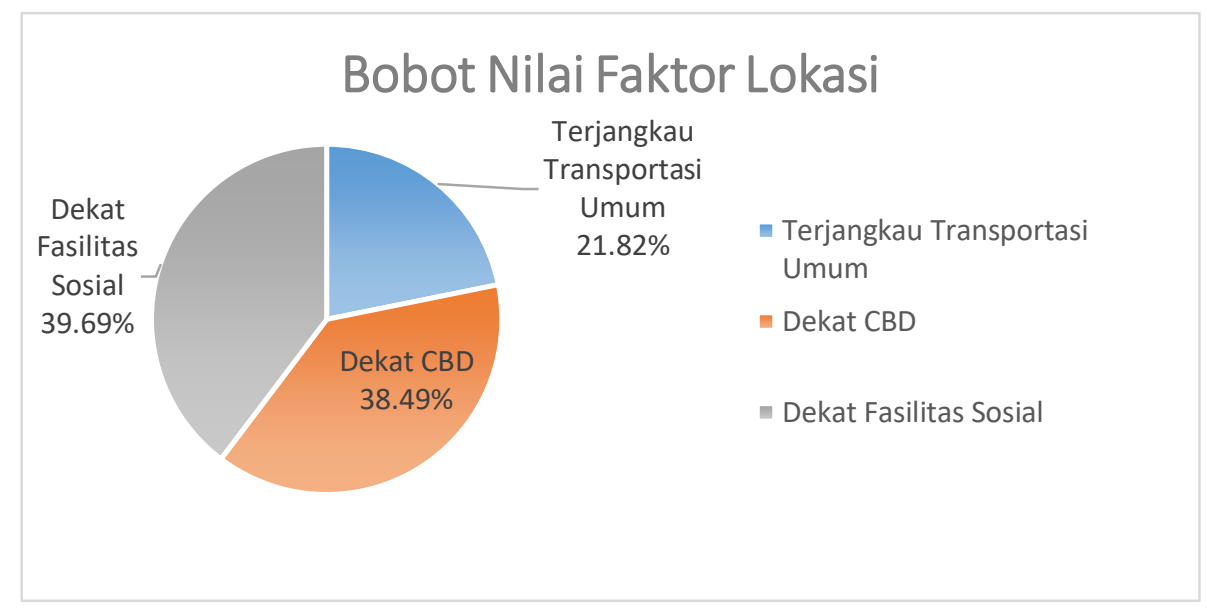

Gambar 5. Bobot nilai faktor lokasi

Terdapat empat subfaktor pada faktor fasilitas apartemen yang menjadi kriteria penilaian, setelah dilakukan analisis, didapatkan bobot nilai terbesar pada subfaktor sarana utilitas (air bersih, jaringan listrik, gas, jaringan telepon, tanda bahaya/alarm, dan jaringan drainase) sebesar 33,69\%. Kemudian subfaktor dengan nilai bobot terkecil adalah subfaktor fasilitas penunjang (kolam renang/fitness center/jogging track/taman bermain anak/ruang serba guna) sebesar $19,04 \%$. Lihat Gambar 6.

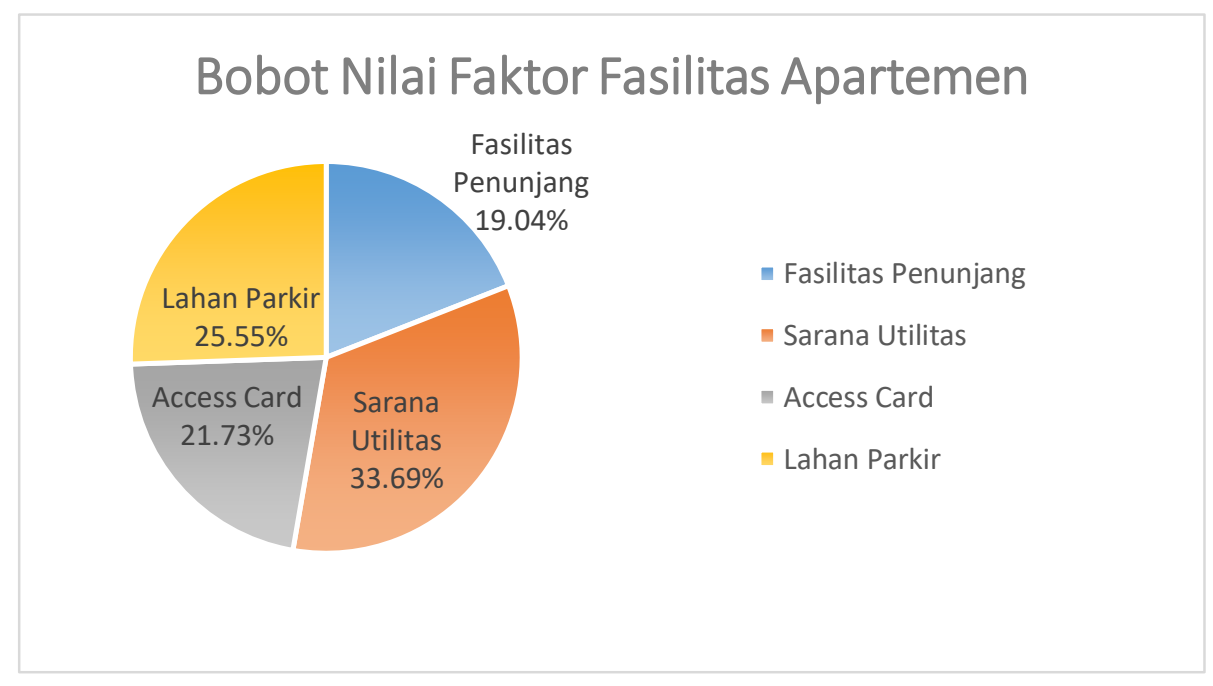

Gambar 6. Bobot nilai faktor fasilitas apartemen

Terdapat dua subfaktor pada faktor legalitas yang menjadi kriteria penilaian, setelah dilakukan analisis, didapatkan bobot nilai terbesar pada subfaktor status sertifikat lahan (HGB murni/HPL) sebesar 60,00\%. Kemudian subfaktor dengan nilai bobot terkecil adalah subfaktor sertifikat kepemilikan unit 40,00\%. Lihat Gambar 7. 


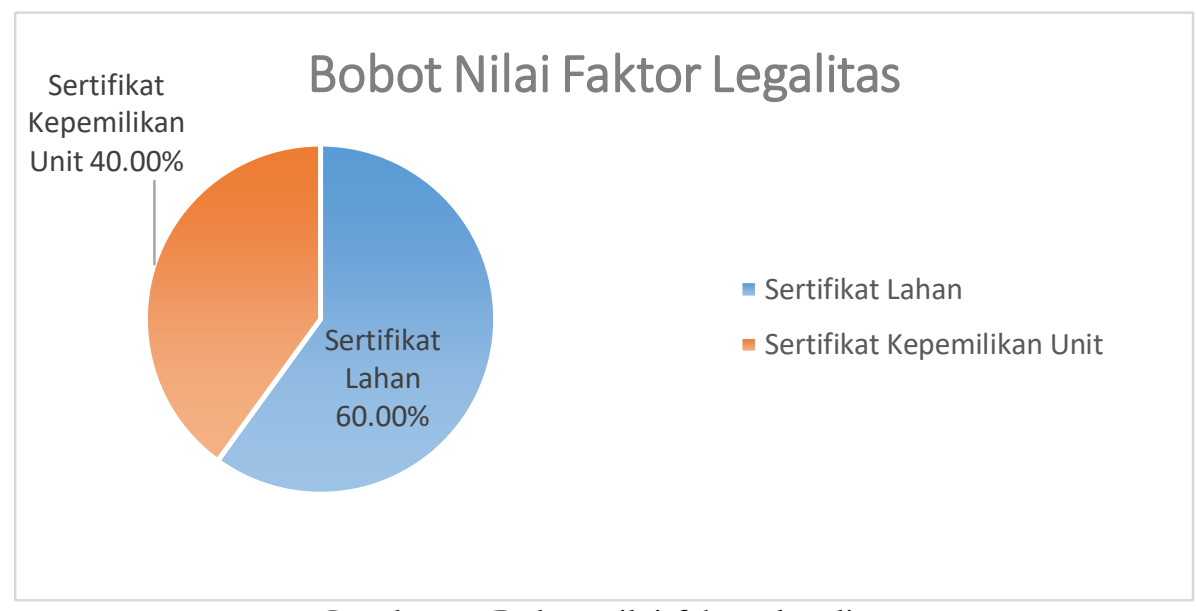

Gambar 7. Bobot nilai faktor legalitas

\section{Analisis Subfaktor Secara Keseluruhan}

Secara keseluruhan, terdapat 16 subfaktor yang digunakan dalam penelitian ini, setelah dianalisi, subfaktor status sertifikat lahan memiliki nilai terbesar, yaitu $14,92 \%$. Sedangkan, subfaktor reputasi kontraktor yang membangun memiliki nilai terkecil, yaitu 1,82\%. Tabel 1 merupakan bobot per kriteria sesuai dengan urutan dari yang paling besar ke yang paling kecil.

Tabel 1. Bobot Nilai Subfaktor keseluruhan

\begin{tabular}{|c|c|c|}
\hline No & Kriteria Pembobotan & Bobot Per Item \\
\hline 1 & Status Sertifikat Lahan (HGB Murni/HPL) & $14,92 \%$ \\
\hline 2 & Sertifikat Kepemilikan Unit & $9,94 \%$ \\
\hline 3 & Harga & $9,77 \%$ \\
\hline 4 & Potensi untuk Disewakan (Yield) dan Kenaikan Harga (Capital Gain) & $7,95 \%$ \\
\hline 5 & $\begin{array}{c}\text { Dekat dengan Fasilitas Sosial (Kesehatan, Pendidikan, Olahraga, Rekreasi, dan Pusat } \\
\text { Perbelanjaan) }\end{array}$ & $7,64 \%$ \\
\hline 6 & Dekat dengan Pusat CBD (Central Business District) & $7,41 \%$ \\
\hline 7 & Kemudahan Pembayaran Cash Bertahap ke Developer (Angsuran) & $7,37 \%$ \\
\hline 8 & Besar DP (Down Payment)/Uang Muka Minimum KPA & $7,04 \%$ \\
\hline 9 & $\begin{array}{l}\text { Sarana Utilitas (Air Bersih, Jaringan Listrik, Gas, Jaringan Telepon, Tanda Bahaya/ Alarm, } \\
\text { dan Jaringan Drainase) }\end{array}$ & $5,22 \%$ \\
\hline 10 & Terjangkau Oleh Transportasi Umum & $4,20 \%$ \\
\hline 11 & Ketersediaan Lahan Parkir & $3,96 \%$ \\
\hline 12 & Desain Fasad Apartemen (Modern/Klasik/Mediteranian/Kolonial) & $3,53 \%$ \\
\hline 13 & Acces Card Khusus Penghuni & $3,37 \%$ \\
\hline 14 & $\begin{array}{c}\text { Fasilitas Penunjang (Kolam Renang/Fitness Center/Jogging Track/Taman Bermain } \\
\text { Anak/Ruang Serba Guna) }\end{array}$ & $2,95 \%$ \\
\hline 15 & Nama Besar Pengembang (Developer) & $2,92 \%$ \\
\hline 16 & Reputasi Kontraktor yang Membangun & $1,82 \%$ \\
\hline
\end{tabular}




\section{SIMPULAN}

Berdasarkan hasil penelitian serta analisis data dan pembahasan yang telah dilakukan, maka dapat dihasilkan kesimpulan yang merupakan jawaban dari rumusan masalah yang dikemukakan. Adapun kesimpulan yang dimaksud adalah sebagai berikut:

1. Faktor yang mempengaruhi masyarakat dalam memilih apartemen, antara lain:

A. Faktor Produk, terdiri atas subfaktor: Potensi untuk Disewakan (Yield) dan Kenaikan Harga (Capital Gain) (7,95\%), Nama Besar Pengembang (Developer) (2,92\%), Reputasi Kontraktor yang Membangun (1,82\%), dan Desain Fasad Apartemen (Modern/Klasik/Mediteranian/Kolonial) (3,53\%).

B. Faktor Persepsi Harga, terdiri atas subfaktor: Harga (9,77\%), Besar DP (Down Payment)/Uang Muka Minimum KPA (7,04\%), dan Kemudahan Pembayaran Cash Bertahap ke Developer (Angsuran) $(7,37 \%)$.

C. Faktor Lokasi, terdiri atas subfaktor: Terjangkau oleh Transportasi Umum (4,20\%), Dekat dengan Pusat CBD (Central Business District) (7,41\%), dan Dekat dengan Fasilitas Sosial (Kesehatan, Pendidikan, Olahraga, Rekreasi dan Pusat Perbelanjaan) (7,64\%).

D. Faktor Fasilitas Apartemen, terdiri atas subfaktor: Fasilitas Penunjang (Kolam Renang/FitnessCenter/Jongging Track/Ruang Serba Guna) (2,95\%), Sarana Utilitas (Air Bersih, Jaringan Listrik, Telepon, Drainase, Gas, Tanda Bahay/Alarm) (5,22\%), Access Card Khusus Penghuni (3,37\%), dan Ketersediaan Lahan Parkir $(3,96 \%)$.

E. Faktor Legalitas, terdiri atas subfaktor: Status Sertifikat Lahan (HGB Murni/HPL) (14,92\%) dan Sertifikat Kepemilikan Unit (9,94\%).

2. Berdasarkan pengolahan kuisioner yang telah dilakukan penulis terhadap keputusan masyarakat dalam memilih apartemen di Kota Surakarta, didapatkan hasil bahwa subfaktor Status Sertifikat Lahan (HGB Murni/HPL) merupakan faktor yang paling mempengaruhi keputusan masyarakat dalam memilih apartemen di Kota Surakarta. Sedangkan subfaktor Reputasi Kontraktor yang Membangun merupakan faktor yang paling tidak mempengaruhi keputusan masyarakat dalam memilih apartemen di Kota Surakarta.

\section{UCAPAN TERIMAKASIH}

Peneliti mengucapkan terimakasih kepada Tuhan Yang Maha Kuasa, kedua orang tua dan keluarga yang telah memberikan dukungan baik materil maupun non material, serta kepada Program Studi Teknik Sipil Universitas Sebelas Maret Surakarta atas ilmu yang diberikan sehingga dapat membantu penyelesaian penyusunan skripsi ini.

\section{REFERENSI}

Apriyanto, Agus.,2008, "Perbandingan Kelayakan Jalan Beton Dan Aspal Dengan Metode Analityc Hierarchy Process (AHP) (Studi Kasus Jalan Raya Demak-Godong)”, Thesis, Program Pascasarjana Universitas Diponegoro.

Apriyanto, Joko Hadi, Gandhiadi, G.K. \& Nilakusumawati, Desak Putu Eka., 2014, "Pemilihan Kriteria dalam Pembuatan Kartu Kredit dengan Menggunakan Metode Fuzzy AHP”, Vol. 3 No. 1.

Bourne, Larry., 1971, "Internal Stucture of The City”, Oxford University Press. New York.

Catanese, Antony J. And James C. Synder., 1989, “Perencanaan Kota edisi Kedua”. Erlangga. Jakarta.

Goodall, 1972, “Grub: The Bush Baby Boston: Houghton Mifflin”, Boston : Houghton Mifflin.

Hutagalung, Arie Sukanti., 2007, "Condominium dan Permasalahannya”, Badan Penerbit Fakultas Hukum Universitas Indonesia. Depok.

Luhst, K. M, 1997, “Real Estate Evaluation”, Principles Aplication Press. USA.

Montgomery, Melanie and Curtis Carey, 2006, "Housing Mobility and Location Choice: A Review of the Literature”. Jurnal Urbanet, Department of Urban and Regional Planning Curtin University.

Onggo, Yance dkk, 2018, "Faktor yang Menentukan Keputusan Membeli Apartemen”, Jurnal. Program MM Sekolah Bisnis dan Ekonomi, Universitas Prasetya Mulya.

Rabinowitz, H.Z., 1988, “Real Estate Planning”, McGraw Hill Inc. New York.

Saaty, T. L. dan Vargas L. G., 2006, "Decision Making with the Analytic Network Process: Economic, Political, Social and Technological Applications with Benefits, Opportunities, Costs and Risks", Springer. New York.

W.J.S, Poerwadarminta., 1991, “Kamus Umum Bahasa Indonesia”, Balai Pustaka. Jakarta. 